$\begin{array}{r}\text { Volume and Issues Obtainable at Center for Sustainability Research and Consultancy } \\ \text { Review of Politics and Public Policy in Emerging Economies } \\ \text { ISSN: 2708-3829 (E): 2708-356X } \\ \text { Volume 1: No. 2, December 2019 } \\ \text { CSRᄃ } \\ \text { Journal homepage: www.publishing.globalcsrc.org/rope } \\ \hline\end{array}$

\title{
Subsidies in the Fisheries Sector of Malaysia: Impact on Resource Sustainability
}

\author{
${ }^{1}$ Wen Chiat Lee, K. Kuperan Viswanathan \\ ${ }^{1}$ Senior Lecturer in Agricultural Economics, Universiti Utara Malaysia \\ ${ }^{2}$ Universiti Utara Malaysia, Sintok, Malaysia: kuperan@uum.edu.my
}

\begin{tabular}{l}
$\quad$ ARTICLE DETAILS \\
\hline History \\
Revised format: November 2019 \\
Available Online: December 2019
\end{tabular}

Keywords

Fisheries Subsidies, Sustainability, Small-Scale

Fisheries, Good and Bad

Subsidies, Subsidy Policy

JEL Classification:

JEL Classificatic

OPEN ACCESS

\begin{abstract}
Subsidies are a form of support provided to consumers and producers by government to enhance the welfare. Fishers in Malaysia receive various type of subsidies. Fisheries subsidies however are a challenge because it can work against fishers' welfare if the fisheries subsidies lead to over fishing and resource depletion. In this paper, we explore the impacts of fisheries subsidies on small-scale fishers in Malaysia and suggest ways to improve the subsidies scheme so that the twin roles of improving fishers' welfare and fisheries sustainability are achieved. Data on fisheries subsidies and fisheries production in Peninsular Malaysia is used in this study.
\end{abstract}

(C) 2019 The authors, under a Creative Commons AttributionNonCommercial 4.0

Corresponding author's email address: kuperan@uum.edu.my

Recommended citation: Lee, W. C. \& Viswanathan, K. K., (2019). Subsidies in the Fisheries Sector of Malaysia: Impact on Resource Sustainability. Review of Politics and Public Policy in Emerging Economies, 1(2), 79-85

DOI: $10.26710 /$ rope.v1i2.1135

\section{Introduction}

Internet is Fishers are given subsidies in Malaysia to improve their welfare. The subsidies are in the form of price support, income support, input support and landing incentives. In the last federal government budget announced in October 2019, the government continues to provide fishers with monthly allowance of RM250 as form of income support. In addition, fishers also receive a diesel subsidy of $\$ 0.53$ per liter.

In much of Malaysia, the fisheries resources are heavily fished and fishers are facing resource sustainability issues. Malaysian fishers catch around one million tons of fish and crustaceans annually. About 40,000 tons of fish and fish products are kept as frozen reserves as well (David 2018). Thus, fisheries subsidies pose a challenge if the subsidies lead to more fishing effort leading to further resource depletion. The subsidies can be considered harmful if the subsidies lead to stock depletion. There are three categories of subsidies namely beneficial subsidies, ambiguous subsidies and harmful subsidies. 
Beneficial subsidies are subsidies that reduce capacity effort and help the artisanal fishers to increase landings and incomes and minimize by-catch. Examples of government expenditure that can be considered as beneficial subsidies are budgets allocated for research and development and fisheries management. Harmful subsidies are those that result in capacity-enhancement in the fisheries that lead to overfishing (Lee \& Viswanathan, 2016). The example of harmful fisheries subsidies are financial support for boat construction and fleet modernization and fuel support that promotes overfishing (World Wildlife Fund, 2011). In this paper, we attempt to explore the impacts of fisheries subsidies on small-scale fishers in Malaysia and suggest ways to improve the subsidies scheme so that the twin roles of improving fishers' welfare and fisheries sustainability are achieved.

\section{Fisheries subsidies in Malaysia}

The fisheries subsidies stood at RM 524.12 million in the year 2017 (LKIM, 2017). Fuel subsidies accounted for about 60 percent of total fisheries subsidies (RM314.08 million). Fuel subsidies are given for fishers to lower the cost of fishing by reducing the total expenditure on fuel for harvesting fish and therefore is considered as bad subsidies. Living subsidies accounted for 31.69 percent of total fisheries subsidies or RM166.07 million. The function of living subsidies is to provide income support to fishers and address the income instability faced by fishers due to their inability to fish during the monsoon season due to rough weather conditions (Ali et al., 2017). Thus, the living subsidies are considered as good or beneficial subsidies. Moreover, catch incentives were also given to fishers based on the fishing zones operated by the fishers. A total of RM 6.78 million were given to fishers as catch incentives in the year 2017. Zone A, B, C fishers receive catch incentives of RM0.10 per kilogram while Zone C2 fishers receive RM0.20 per kilogram (Jamal et al., 2017). However, trash fish is excluded from the catch incentives (for Zone B, C and C2) though trash fish accounted for a significant 40 percent of total landings by trawlers.

A total of RM2.01 million value of natural disaster scheme was also given to fishers in year 2017 and also RM6.43 million worth of infrastructure and development subsidies (construction of new or reconstruction of jetty for the fishers to land fish or construction of aquaculture landing site) was also given to fishers in year 2017.

Table 1: Malaysian Government expenditure on Fisheries Subsidies 2016-2017

\begin{tabular}{|l|l|l|l|l|l|l|}
\hline $\begin{array}{l}\text { Type of } \\
\text { subsidy }\end{array}$ & $\begin{array}{l}\text { Year 2016 } \\
\text { (Amount) } \\
\text { RM } \\
\text { millions }\end{array}$ & $\begin{array}{l}\text { Year 2016 } \\
\text { (Percentage) }\end{array}$ & $\begin{array}{l}\text { Year 2017 } \\
\text { (Amount) } \\
\text { RM } \\
\text { millions }\end{array}$ & $\begin{array}{l}\text { Year 2017 } \\
\text { (Percentage) }\end{array}$ & Classification & Valuation \\
\hline $\begin{array}{l}\text { Fuel and } \\
\text { Diesel }\end{array}$ & 70.58 & 21.63 & 314.08 & 59.93 & $\begin{array}{l}\text { Capacity } \\
\text { Enhancing }\end{array}$ & Bad \\
\hline $\begin{array}{l}\text { Living } \\
\text { allowances }\end{array}$ & 174.24 & 53.39 & 166.07 & 31.69 & Beneficial & Good \\
\hline $\begin{array}{l}\text { Catch } \\
\text { incentives }\end{array}$ & 70.70 & 21.66 & 35.53 & 6.78 & $\begin{array}{l}\text { Capacity } \\
\text { enhancing }\end{array}$ & Bad \\
\hline $\begin{array}{l}\text { Other } \\
\text { support } \\
\text { (Natural } \\
\begin{array}{l}\text { Disaster } \\
\text { Assistance } \\
\text { Scheme) }\end{array}\end{array}$ & 1.89 & 0.60 & 2.01 & 0.37 & Ambiguous & Good and \\
\hline $\begin{array}{l}\text { Infrastructure } \\
\text { development }\end{array}$ & 8.96 & 2.72 & 6.43 & 1.23 & Beneficial & Good \\
\hline Total & 326.37 & 100 & 524.12 & 100 & & \\
\hline
\end{tabular}




\begin{tabular}{|l|l|l|l|l|l|l|}
\hline $\begin{array}{l}\text { Number of } \\
\text { fishers }\end{array}$ & 58,621 & 56,149 & & & \\
\hline
\end{tabular}

Figure 1 shows the five fisheries zones in Malaysia namely Zone A, Zone B, Zone C, Zone C2 and Zone C3.

Figure 1: Fisheries Zones in Malaysia

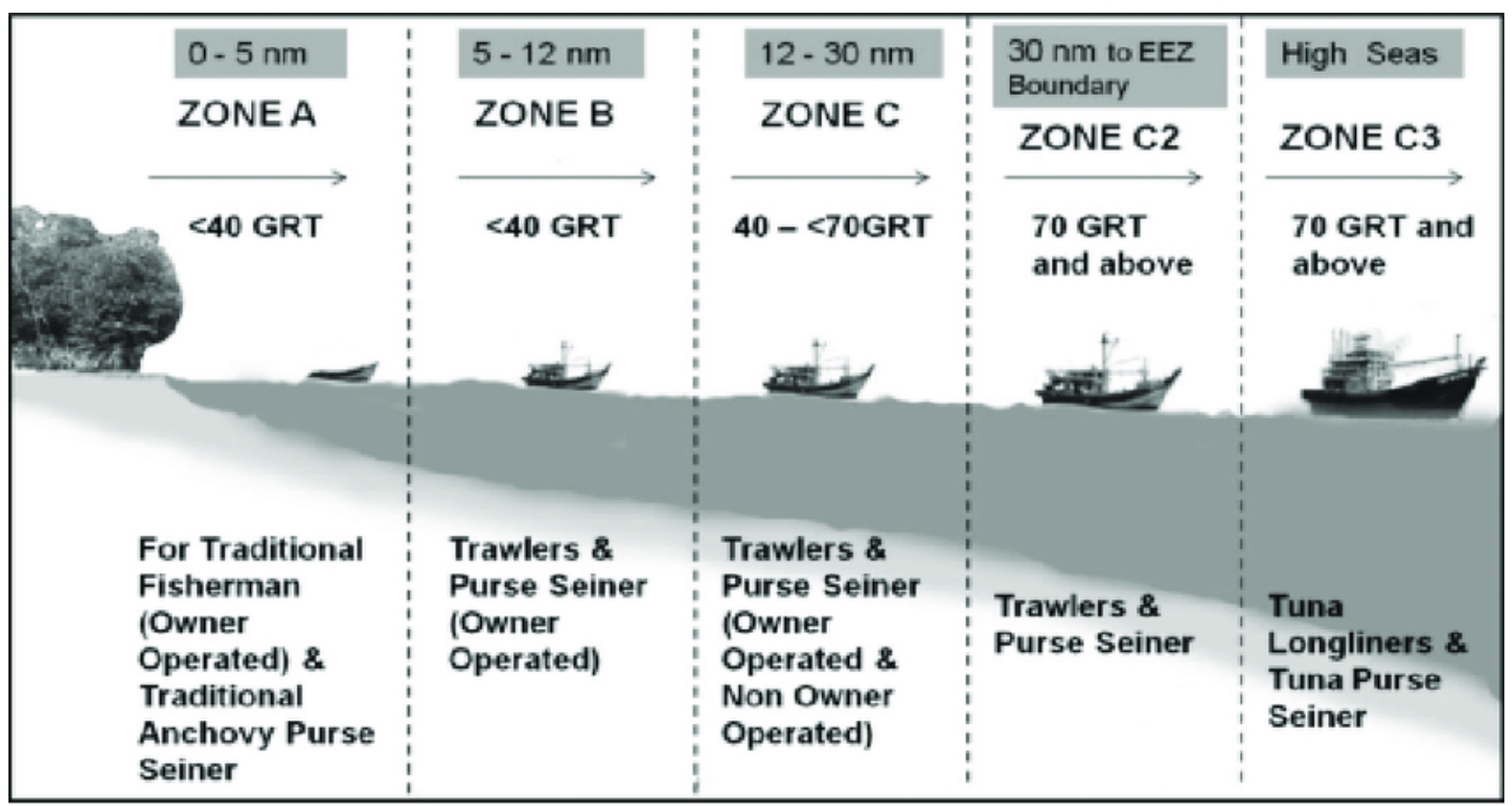

Source: Department of Fisheries Malaysia (2018)

Artisanal fishers or traditional fishers who use purse seiner operates in Zone A. From Zone B onwards to Zone C, C2 and C3, the fishers use trawl to fish. The use of trawls by the fishers destroy the fisheries resources because most of the trash fish (about 40 percent) are mostly captured by trawlers. Trash fish are juveniles' fish or fingerlings which have not grown into full adults. When large amounts of trash fish are landed, the number of juvenile fish that could grow into adult fish is reduced and thus leads to unsustainable fisheries resources in the long run. It is therefore important to manage and regulate the use of trawls and reduce the number of trash fish captured.

\section{Malaysian Fisheries Resources and Fishing Effort}

Malaysian outboard powered vessels are increasing every year from 11,908 units in year 2007 to 21,493 units in the year 2013. This shows that the fishing effort has increases and this may lead to depletion of fisheries resources. The inboard-powered vessels also is still high, recorded at 11,917 units in the year 2013. The inboard-powered vessels has a sharp drop from 18,248 units in year 2010 to 11,661 units in year 2011. However, the inboard-powered vessels continue to increase to 11,685 units in year 2012 and further increase to 11,917 units in year 2013. Again, this shows that the fishing effort in Malaysia seawaters has increased from year to year. The total number of licensed fishing boats by tonnage from year 2007 to year 2013 is shown in Table 2. 
Table 2: Total number of licensed fishing boats by tonnage, 2007-2013

\begin{tabular}{|l|l|l|l|l|l|r|c|}
\hline Year & $\begin{array}{l}\text { Non- } \\
\text { powered }\end{array}$ & $\begin{array}{l}\text { Outboard- } \\
\text { powered }\end{array}$ & $\mathbf{\%} \Delta$ & $\begin{array}{l}\text { Inboard- } \\
\text { powered }\end{array}$ & \% $\Delta$ & Total & $\begin{array}{c}\text { \% } \\
\Delta\end{array}$ \\
\hline 2007 & 113 & 11,908 & - & 12,140 & - & 24,161 & - \\
\hline 2008 & 100 & 13,247 & $\begin{array}{l}11.2 \\
4\end{array}$ & 12,129 & -0.09 & 25,476 & 5.44 \\
\hline 2009 & 109 & 18,270 & 37.9 & 12,119 & -0.08 & 30,498 & 19.71 \\
& & 2 & & & & \\
\hline 2010 & 89 & 19,255 & 5.39 & 18,248 & 50.57 & 37,592 & 23.26 \\
\hline 2011 & 52 & 19,761 & 2.63 & 11,661 & -36.10 & 31,474 & -16.27 \\
\hline 2012 & 71 & 19,841 & 0.40 & 11,685 & 0.21 & 31,597 & 0.39 \\
\hline 2013 & 66 & 21,493 & 8.33 & 11,917 & 1.99 & 33,476 & 5.95 \\
\hline $\begin{array}{l}\text { Source: Annual fisheries statistics, Department } \\
\text { of fisheries Malaysia (various issues) }\end{array}$ & & & & \\
\hline
\end{tabular}

Malaysian marine fish landings by trawlers also decrease from year to year. This shows that the fisheries resources are depleting. Studies by Ali et. al. (2017) showed that the fish landings by trawlers in three states namely Perlis, Kedah and Perak had decreased. For example, fish landings by boat size with gross tonnage 25 to 39.9 GRT in Perlis had decreased by 18 percent from year 2011 to 2013. Other state such as Perak also recorded a decrease of 9.3 percent in fish landings from year 2011 to 2013. Subsidies that further increase fishing effort will lead to fisheries resources depletion. The reduced in landing of marine fish in Perlis and Perak seawaters indicate that fisheries depletion is there. This shows that the fisheries resources are unsustainable in the long run. The landings of marine fish by trawlers from year 2011 to 2013 is shown in Table 3.

Table 3: Landings of marine fish by trawlers, 2011-2013

\begin{tabular}{|c|c|c|c|c|}
\hline State & Year & $\begin{array}{lll}\text { Boat } \quad \text { size } & \text { (gross } \\
\text { tonnage, } & \text { GRT })\end{array}$ & Landings (tones) & $\begin{array}{l}\% \Delta \text { from } \\
2011-2013\end{array}$ \\
\hline \multirow[t]{6}{*}{ Perlis } & 2011 & $25-39.9$ & 13,642 & $-18.0 \%$ \\
\hline & 2012 & & 11,193 & \\
\hline & 2013 & & 10,333 & \\
\hline & 2011 & $40-69.9$ & 38,530 & $-46.4 \%$ \\
\hline & 2012 & & 31,216 & \\
\hline & 2013 & & 20,668 & \\
\hline \multirow[t]{6}{*}{ Kedah } & 2011 & $25-39.9$ & 18,187 & $+3.8 \%$ \\
\hline & 2012 & & 15,571 & \\
\hline & 2013 & & 18,876 & \\
\hline & 2011 & $40-69.9$ & 17,845 & $+4.4 \%$ \\
\hline & 2012 & & 18,664 & \\
\hline & 2013 & & 18,629 & \\
\hline \multirow[t]{6}{*}{ Perak } & 2011 & $25-39.9$ & 18,394 & $-9.3 \%$ \\
\hline & 2012 & & 22,356 & \\
\hline & 2013 & & 16,681 & \\
\hline & 2011 & $40-69.9$ & 70,916 & $+18.1 \%$ \\
\hline & 2012 & & 77,811 & \\
\hline & 2013 & & 83,739 & \\
\hline
\end{tabular}


Table 4: Characteristics of fishing operations, selected boats by fishing zone

\begin{tabular}{|l|c|c|c|}
\hline Zone & A & B & C \\
\hline Gear & Traditional & & \\
\hline Trip/month & 18 & 13 & 8 \\
\hline Income/month & 1319 & 2737 & 15,116 \\
\hline Catch and revenue & & & \\
\hline Catch (kg/trip) & 122 & 2463 & 8258 \\
\hline Value of fish (RM) & 142 & 424,660 & $1,528,733$ \\
\hline Catch incentive (RM) & 220 & 668 & 584 \\
\hline Livelihood subsidy/month (RM) & 54 & 225 & 200 \\
\hline Brim & 382 & 4334 & 0 \\
\hline Fuel subsidy/month (RM) & 2118 & 8018 & 20,881 \\
\hline Total gross income (RM) & 18.05 & 54.06 & 23.86 \\
\hline Percentage income from fuel subsidy & 37.69 & 65.87 & 27.61 \\
\hline Percentage income from subsidy & 66.79 & 32.94 & 63.69 \\
\hline Fuel as percent of operating cost & & & \\
\hline Operating expenses & 7250 & 11,600 & 40,455 \\
\hline Cost of fuel price (RM / month) & & & \\
\hline Cost of ice (RM/month) & 20 & 150 & 200 \\
\hline Cost of food (Rm/month) & 7250 & 11,600 & 40,455 \\
\hline Cost of bait (RM/month) & 427 & 513 & 641 \\
\hline Total monthly operating expenses (RM/month) & 90 & 400 & 500 \\
\hline Miscellaneous (RM/month) & 211.64 & $1,945.45$ & $10,676.27$ \\
\hline Net income (RM) & $(2017)$ & & \\
\hline Source: Fieldwork-survey by Ali et. al. & & & \\
\hline
\end{tabular}

Fieldwork by Ali et. al. (2017) also showed the characteristics of fishers by fishing zones. All the fishers in Zone $\mathrm{A}$, Zone $\mathrm{B}$ and Zone $\mathrm{C}$ received significant amount of subsidies. The percentage of income earned from subsidies for Zone A, Zone B and Zone $\mathrm{C}$ fishers are 37.69 percent, 65.87 percent and 27.61 percent. The livelihood subsidies are beneficial to support the fishers livelihood and income. However, the bad or harmful subsidies such as fuel subsidy also contribute significantly to the fishers' income. The fuel subsidy contributes 18.05 percent to Zone A fishers' income, 54.06 percent to Zone B fishers' income and 23.86 percent to Zone $\mathrm{C}$ fishers' income. This indicates that fishers' depend very much on fuel subsidy to fish.

\section{Discussion on Impacts of Subsidies on Fisheries Resources Sustainability 4.1 Impacts of Subsidies on fisheries resources}

The fisheries ecosystems in Malaysia are facing problems of overexploitation, degradation and pollution. The issue is whether programs that provide subsidies to the fisheries sector further worsen these problems or reduce the impacts of these problems. The data on the number of fishing vessels and the fluctuation in landings of catch in the three states of Perlis, Kedah and Perak indicate that the environmental impact of subsidies on fish stocks is significant and a more detailed study on how subsidies affect the fish stocks is needed.

\subsection{The Overcapitalization Effect}


There is an excessive fishing effort and overcapacity especially on the west coast of Peninsular Malaysia. The few research studies undertaken by the Department of Fisheries indicate that resources are heavily stressed and are being currently fished beyond their maximum sustainable yield. Biomass estimates are said to be down to $6 \%$ of original stock levels. Analysis of standardized fishing effort and yield indicate that the 1996 effort is $135-200 \%$ of the level needed to harvest the MSY.

These findings are further demonstrated in the increasing fishing effort arising from the increase in the number of trawlers and purse seiners and the number of power boats. Table 2 earlier also shows that the number of outboard-powered boats increased by $38 \%$ between 2008 and 2009. The total number of licensed boats increased by about $6 \%$ between 2012 and 2013. This represents a significant increase in fishing capacity (more fishing boats) in an already stressed fishing environment.

\subsection{Effects of Fish Landing Subsidies}

The overcapitalization effect can also be determined by looking at information on landing of marine fish by different types of fishing boats. Table 3 shows landings of marine fish by trawlers in Malaysia, namely in Perlis, Kedah and Perlis. Fishers are given landing incentives according to the size the catch and the rate is set at 10 cents per $\mathrm{kg}$ for $\mathrm{A}, \mathrm{B}$ and $\mathrm{C}$ boats and 20 cents for $\mathrm{C} 2$ boats. The maximum payment allowed for boat $\mathrm{A}$ is between RM150 to RM300 per month. The maximum for the B, C and C2 boats are RM750, RM1500 and RM5000 respectively. The boat $\mathrm{C}$ has the highest monthly catch per trip, about $8528 \mathrm{~kg}$. This is followed by boat Zone B at $2463 \mathrm{~kg}$, and the traditional boat (boat A) has a catch of around $122 \mathrm{~kg}$ per trip.

The number of catches, and coupled with the subsidy, the monthly income is estimated at RM2, 118 fishing boats for a fisher from Zone A, RM8018 for Zone B, and RM20,881 for Zone C. Fishers from boat $\mathrm{B}$ is found most likely to benefit from fuel subsidies since fuel cost as percentage of operating cost was $67 \%$, followed by boat C $64 \%$, and boat B33\%. If all subsidies such as fuel subsidy, catch incentives and livelihood subsidy is not provided to fishers, fishing boat A most affected because without the subsidies, their monthly income just to RM212 a month compared to boat B RM1945 and boat C as much as RM10,676 a month.

Finding from the survey by Ali et.al. (2017) has been supported by finding from focus group discussion with participants from various types of fishers to elicit their perceptions of the impacts of subsidies on their livelihoods and fisheries. The results show that fuel subsidy is the most preferred subsidy for all types of fishing. For the artisanal fisherman (boat A), fishing inputs such as boat, nets, engine, GPS, life jackets are the second preferred subsidy (grants) followed by monthly allowance subsidy.

\section{Conclusion}

The data on both landings and number of vessels indicate that the fishing effort is increasing. The subsidies for fisheries especially the landings incentives, fuel subsidies and income support seem to encourage more effort to be introduced in the fishery. This in the long run will further deplete the fisheries resources. The depletion will lead to lower catches for fishers thus leading to lower incomes and welfare levels. These subsidies may be only a short term approach for helping fishers to stay above the poverty line. Continuous provision of subsidies will lead to further worsening of fishing income. Policies should focus on reducing fishing effort and removing surplus fishers from the fishing industry. Thus efforts to engage fishers in alternative income activities such as aquaculture and tourism related ventures may be the way forward.

\section{References}

Ali, J., Abdullah, H., Noor, M.S.Z., Viswanathan, K.K., Islam, G.N. (2017). The Contribution of Subsidies on the Welfare of Fishing Communities in Malaysia. International Journal of Economics and Financial Issues, 7(2), 641-648.

David, A. (2018). Malaysia's fish stocks in danger of being depleted. New Straits Times. Retrieved from 
https://www.nst.com.my/news/nation/2018/12/436862/malaysias-fish-stock-danger-beingdepleted

Department of Fisheries Malaysia (2018). Malaysian Fisheries Zones. Retrieved from http://www.dof.gov.my/index.php/pages/view/42

Lee, W.C. \& Viswanathan, K.K. (2016). Harmful Fisheries Subsidies in Southeast Asia (ASEAN). Paper presented at the Proceedings of 3rd Annual EcoFi Symposium, Kedah, Malaysia (pp. 18-23).

LKIM (2016). Annual Report 2016 of Malaysian Fisheries Development Authority. Retrieved from: https://drive.google.com/file/d/1iNmqlvV8GqINKt8OnDS_p4q6rDrUAizj/view

LKIM (2017). Annual Report 2017 of Malaysian Fisheries Development Authority. Available from: https://drive.google.com/file/d/1cLAFb8N-Xb-aItFSOfR5tKHWhUi0wkqS/view

World Wildlife Fund, 2011. Reforming Fisheries Subsidies. Retrieved from World Wildlife Fund Website: http://awsassets. panda.org/downloads/wwf briefing on_subsidies_reform.pdf 